\title{
Author Correction: Automated design of a convolutional neural network with multi-scale filters for cost-efficient seismic data classification
}

\section{Zhi Geng(D) \& Yanfei Wang (D)}

Correction to: Nature Communications https://doi.org/10.1038/s41467-020-17123-6, published online 3 July 2020.

The original version of this Article contained a typo in Eq. (1), in which the subscript of $\beta\|W\|_{\mathrm{TV}}$ was given incorrectly. The correct expression is $\beta\|W\|_{L_{2}}$. Correspondingly, in the following text, "TV regularization of $W$ " should be corrected as " $l_{2}$ regularization of $W$ "; " $\beta\|W\|_{\mathrm{TV}}$ is used" should be corrected as " $\beta\|W\|_{l_{2}}$ is used".

Published online: 22 October 2020

\begin{abstract}
(c) (1) Open Access This article is licensed under a Creative Commons Attribution 4.0 International License, which permits use, sharing, adaptation, distribution and reproduction in any medium or format, as long as you give appropriate credit to the original author(s) and the source, provide a link to the Creative Commons license, and indicate if changes were made. The images or other third party material in this article are included in the article's Creative Commons license, unless indicated otherwise in a credit line to the material. If material is not included in the article's Creative Commons license and your intended use is not permitted by statutory regulation or exceeds the permitted use, you will need to obtain permission directly from the copyright holder. To view a copy of this license, visit http://creativecommons.org/licenses/by/4.0/.
\end{abstract}

(c) The Author(s) 2020 